\title{
Sulfonated inhibitors of the RNA editing ligases validate the essential role of the MRP1/2 proteins in kinetoplastid RNA editing
}

\author{
VAIBHAV MEHTA, ${ }^{1,2}$ HOUTAN MOSHIRI, ${ }^{1,2}$ AKSHAYA SRIKANTH ${ }^{2}{ }^{2}$ SMRITI KALA, ${ }^{2}$ JULIUS LUKEŠ, ${ }^{3}$ \\ and REZA SALAVATI', \\ ${ }^{1}$ Department of Biochemistry, McGill University, Montreal, H3G1Y6 Quebec, Canada \\ ${ }^{2}$ Institute of Parasitology, McGill University, Ste. Anne de Bellevue, H9X 3V9 Quebec, Canada \\ ${ }^{3}$ Institute of Parasitology, Biology Centre and Faculty of Science, University of South Bohemia, 37005 České Budějovice (Budweis), \\ Czech Republic
}

\begin{abstract}
The RNA editing core complex (RECC) catalyzes mitochondrial U-insertion/deletion mRNA editing in trypanosomatid flagellates. Some naphthalene-based sulfonated compounds, such as C35 and MrB, competitively inhibit the auto-adenylylation activity of an essential RECC enzyme, kinetoplastid RNA editing ligase 1 (KREL1), required for the final step in editing. Previous studies revealed the ability of these compounds to interfere with the interaction between the editosome and its RNA substrates, consequently affecting all catalytic activities that comprise RNA editing. This observation implicates a critical function for the affected RNA binding proteins in RNA editing. In this study, using the inhibitory compounds, we analyzed the composition and editing activities of functional editosomes and identified the mitochondrial RNA binding proteins 1 and 2 (MRP1/2) as their preferred targets. While the MRP1/2 heterotetramer complex is known to bind guide RNA and promote annealing to its cognate pre-edited mRNA, its role in RNA editing remained enigmatic. We show that the compounds affect the association between the RECC and MRP1/2 heterotetramer. Furthermore, RECC purified posttreatment with these compounds exhibit compromised in vitro RNA editing activity that, remarkably, recovers upon the addition of recombinant MRP1/2 proteins. This work provides experimental evidence that the MRP1/2 heterotetramer is required for in vitro RNA editing activity and substantiates the hypothesized role of these proteins in presenting the RNA duplex to the catalytic complex in the initial steps of RNA editing.
\end{abstract}

Keywords: trypanosome; RNA editing; MRP1/2; inhibitor; RNA-binding protein; RNA editing initiation

\section{INTRODUCTION}

Most mitochondrial transcripts in kinetoplastids undergo a unique post-transcriptional maturation process known as RNA editing, which is essential for parasite energy generation and viability of both insect procyclic form (PF) and mammalian bloodstream form (BF), and is thus considered a suitable drug target (Schnaufer et al. 2001; Salavati et al. 2012). A multiprotein RNA editing core complex (RECC; a. k.a. the $20 \mathrm{~S}$ editosome) mediates the RNA editing process by coordinated catalytic activities, including endonuclease cleavage, uridylate $(U)$ insertion, $U$ deletion, and RNA ligation, as specified by complementary guide RNA molecules (gRNAs) (Blum et al. 1990; Sturm and Simpson

Corresponding author: reza.salavati@mcgill.ca

Article is online at http://www.rnajournal.org/cgi/doi/10.1261/rna. 075598.120. Freely available online through the RNA Open Access option.
1990; Simpson et al. 2000, 2003; Osato et al. 2009; Aphasizhev and Aphasizheva 2011).

Several naphthalene-based sulfonated compounds, such as C35 and MrB (also referred to as V2 and V4, respectively [Durrant et al. 2010]), competitively inhibit the autoadenylylation and, consequently, the ligation activities of the recombinant kinetoplastid RNA editing ligase 1 (rKREL1) protein from T. brucei; the enzyme responsible for the last step in RNA editing (Amaro et al. 2008; Durrant et al. 2010; Moshiri et al. 2011). C35 also inhibits the auto-adenylylation activity of a related RNA editing ligase, KREL2 (Moshiri et al. 2011), as both ligases have considerable sequence conservation (Worthey et al. 2003). The catalytic mechanism of the RNA editing ligases is identical to ATP-dependent DNA ligases found in eukaryotes,

(C) 2020 Mehta et al. This article, published in RNA, is available under a Creative Commons License (Attribution 4.0 International), as described at http://creativecommons.org/licenses/by/4.0/. 
viruses, and eubacteria (Doherty and Suh 2000). Catalysis follows a three-step process, with (a) activation of the ligase in the first step by the formation of a covalent AMP - ligase intermediate (auto-adenylylation), releasing pyrophosphate. Next, (b) the ligase transfers the AMP to the $5^{\prime}$ phosphate of a nicked RNA, and (c) terminates ligation by forming a phosphodiester bond between the $3^{\prime}$ hydrox$\mathrm{yl}$ and the $5^{\prime}$ adenylylated phosphate, releasing the AMP (Doherty and Suh 2000). KREL1 and KREL2 are proposed to ligate the edited sites post $U$-deletion and $U$-insertion editing, respectively (Huang et al. 2001; Schnaufer et al. 2003). However, knockout studies showed that only KREL 1 is essential for in vivo editing and survival of the parasites (Schnaufer et al. 2001; Drozdz et al. 2002; Gao and Simpson 2003). In the context of purified editing extracts, these compounds inhibit the in vitro RNA-binding capacity of the editosomes, consequentially affecting all in vitro RNA editing activities, suggesting an alternative mode of inhibition (Moshiri et al. 2011, 2015). Moreover, ligase auto-adenylylation enhancement is an unexpected effect of these compounds that is a result of inaccessible endogenous "ligatable" RNA molecules to which these ligases normally deadenylylate to (Moshiri et al. 2011). However, the exact mechanism of action of these compounds in the context of editosomes remained to be determined.

The RECC works with other multiprotein complexes including the RNA Editing Substrate binding Complex (RESC; a.k.a. the mitochondrial RNA binding 1 [MRB1] complex), constituting the RNA editing holoenzyme (Aphasizheva et al. 2014; Read et al. 2016). The RESC consists of the gRNA binding complex (GRBC) and the RNA editing mediator complex (REMC). The GRBC is implicated in gRNA stability and initiation of RNA editing (Weng et al. 2008; Hashimi et al. 2009; Ammerman et al. 2011, 2013), while REMC is critical for $3^{\prime}$ to $5^{\prime}$ progression (Fisk et al. 2008; Ammerman et al. 2010).

Formerly known as the gRNA binding proteins gBP21 and $\mathrm{gBP} 25$, the mitochondrial RNA binding proteins 1 and 2 (MRP1/2) form a $100 \mathrm{kDa}$ stable heterotetrameric complex (Blom et al. 2001; Aphasizhev et al. 2003; Schumacher et al. 2006; Zikova et al. 2008) that associates with the RECC and the RESC in a RNA-dependent manner at low salt concentrations (Allen et al. 1998; Aphasizhev et al. 2003; Weng et al. 2008; Osato et al. 2009). In vitro biochemical analyses of recombinant MRP1/2 and their sensitivity to increasing salt concentrations support the electrostatic nature of their interaction with gRNA (Koller et al. 1997; Schumacher et al. 2006). In addition to its gRNA binding activity, this complex also promotes gRNA melting of stem loop I and gRNA : pre-mRNA annealing (Muller et al. 2001; Muller and Goringer 2002; Aphasizhev et al. 2003; Schumacher et al. 2006). RNA interference analysis of MRP2, either alone or together with MRP1, results in cell growth defects and decreased abundance of edited mRNAs (such as CyB and RPS12) and, in- triguingly, never edited mRNAs (Vondruskova et al. 2005; Fisk et al. 2009), implying that MRP1/2 function may extend beyond mitochondrial transcripts requiring RNA editing. Knockdown studies revealed an effect on the assembly and functionality of the respiratory complexes with a significant decrease in the mitochondrial membrane potential, implying repression of editing in vivo (Zikova et al. 2006). Moreover, immunodepletion of MRP1 from mitochondrial fractions active in RNA editing leads to suppression of in vitro editing (Lambert et al. 1999). Recent in vivo cross-linking analysis reports MRP1/2's role in the editing of minimally edited mRNAs, resulting from a correlation between the binding patterns of MRP1 and the RESC component, MRB8170, across minimally edited mRNAs (Dixit and Lukeš 2018). While the general perception on the role of this heterotetramer remains in RNA matchmaking and annealing, its exact role and function in RNA editing is unclear.

Here, we identify the MRP1/2 proteins as targets of C35 and with its help we show that MRP1/2 inhibition abrogates in vitro RNA editing activity, implicating the MRP1/ 2 accessory complex in RNA editing initiation as proposed earlier.

\section{RESULTS AND DISCUSSION}

\section{C35 inhibits the RNA binding activity of MRP1/2 proteins}

As shown previously, C35 targets and inhibits the formation of the ribonucleoprotein (RNP) complexes on an electro-mobility shift assay (EMSA, G1-G4) (Fig. 1A; Moshiri et al. 2011). We analyzed the content of the most affected RNP (G1) using mass spectroscopy and observed that the MRP1/2 proteins predominantly populate it. This is in accordance with previous observations where incubation with antibodies specific to MRP1 resulted in a supershift of the G1 RNP complex on an EMSA (Allen et al. 1998). While this observation indicated that these proteins were the likely targets for C35 in the G1 RNP, we cannot rule out the possibility of other RNA binding proteins also being targeted, namely TbRBP38, TbRGG1, and TbRGG2 that are present at much lower abundance. Figure 1B summarizes the results obtained from this mass spectrometric study. To validate MRP1/2 as bona fide targets of C35, the compound was covalently conjugated to agarose beads via a N-hydroxysuccinimide linker that binds to the primary amine group on the compound. These beads were used as bait to precipitate the potential target proteins from the T. brucei mitochondrial lysate in the presence or absence of RNase A, since RECC interaction with MRP1/2 heterotetramer is RNase sensitive (Aphasizhev et al. 2003; Osato et al. 2009). Western blotting with antibodies of MRP2 and four RECC proteins (KREPA1, KREPA2, KREL1, and KREPA3) indicated that MRP2 potentially binds directly 

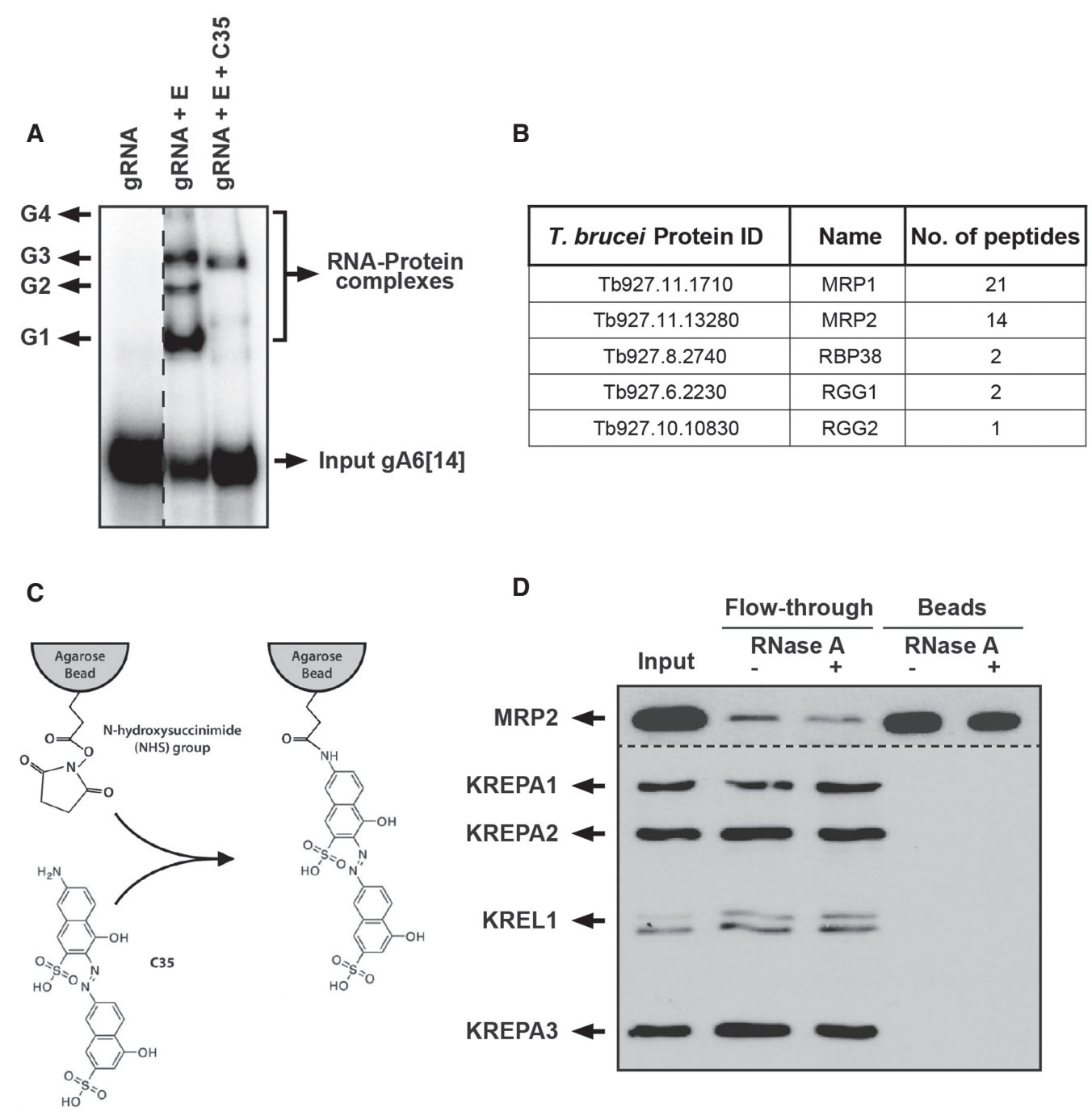

FIGURE 1. MRP1/2 are found in the G1 RNP and bind directly to C35. (A) C35-treated and untreated editosome proteins (E) were incubated with ${ }^{32}$ P-labeled gA6[14] RNA and resolved on 4\% (w/v) TBE gel. Protein-bound RNA is indicated as G1-G4 RNP complexes. (B) The RNA-binding proteins identified in the $\mathrm{G} 1$ complex by tandem mass spectrometry. The corresponding protein identification numbers in $T$. brucei and the number of peptide hits are shown. (C) Covalent conjugation of C35 to the NHS-activated beads through its amine group. (D) Western blot analysis with antibodies against MRP2 (top panel) and KREPA1, KREPA2, KREL1, and KREPA3 (lower panel) analyzing mitochondrial lysate (input), unbound (flow-through), and bound proteins with and without RNase A treatment.

to $\mathrm{C} 35$, as that pull-down is unaffected in the presence of RNase A. In contrast, the RECC proteins (especially KREL1) do not bind at all (Fig. 1D). A majority of the interactions between the MRP1/2 protein complex and their target RNA are electrostatic in nature, as these proteins are rich in arginine residues with a theoretical pl $>9$ (Koller et al. 1997; Schumacher et al. 2006). On the other hand, C35, with its sulfonate groups, is highly electronegative (Durrant et al. 2010), suggesting its interaction with MRP1/2 to also be governed by electrostatic interactions. So, as C35 occupies the RNA-binding regions of the MRP1/2 proteins, they displace any bound RNA and, consequently, the RECC complexes, thereby affecting the association between the two complexes.
Using EMSAs, we next validated C35's effect on the gRNA binding activities of coexpressed recombinant MRP1/2 and KREPA4 (Fig. 2); KREPA4 is an integral RECC protein known to interact with gRNA and is used as a control protein (Salavati et al. 2006; Kala and Salavati 2010). Increasing concentrations of the purified recombinant proteins $(0.1-1600 \mathrm{nM})$ were incubated with a fixed amount of labeled gA6[14] gRNA in the absence or presence of $10 \mu \mathrm{M}$ C35. As seen in Figure 2A, untreated MRP1/2 shows the characteristic pattern of the gRNAMRP1/2 assembly (Zikova et al. 2008): formation of two different complexes corresponding to one or two gRNA molecules bound, which is decreased in the presence of C35, requiring a higher concentration of $\mathrm{MRP} 1 / 2$ to overcome 

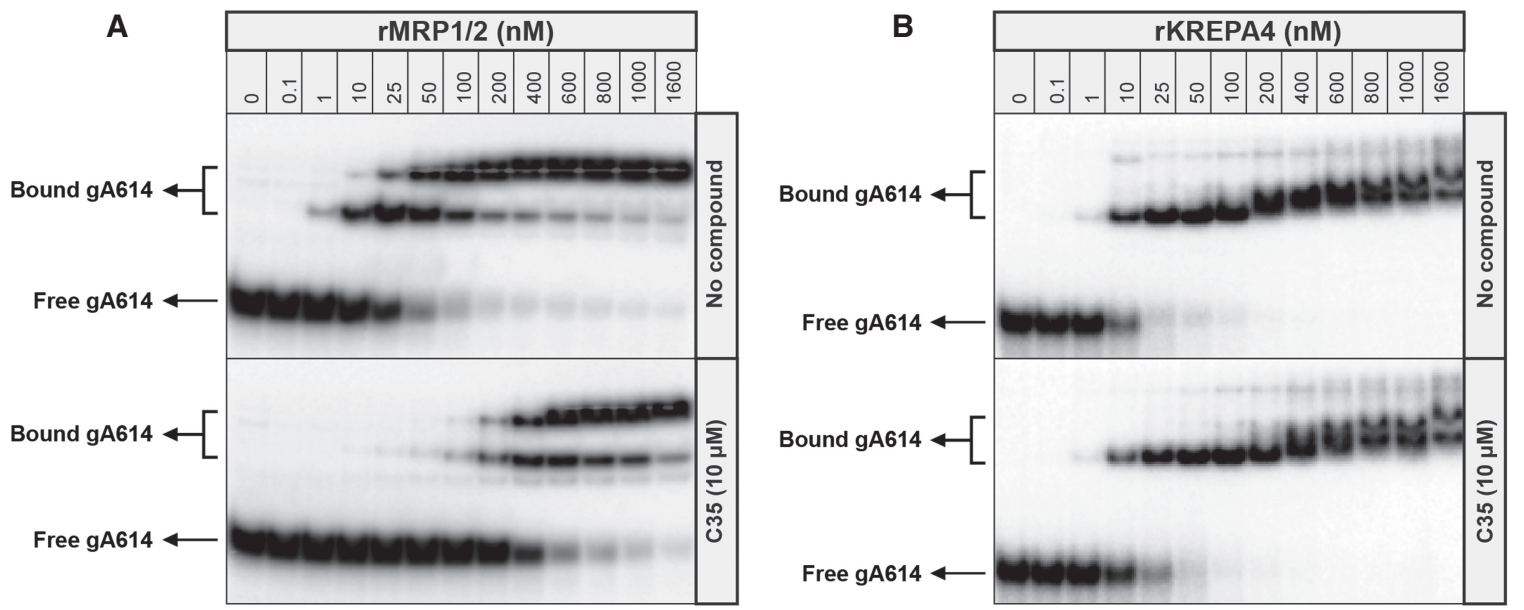

FIGURE 2. C35 affects the RNA binding activity of recombinant MRP1/2 proteins. Increasing concentrations of the respective proteins were incubated with ${ }^{32} \mathrm{P}$-labeled gA6[14] gRNA in the absence and presence of $\mathrm{C} 35$ at $10 \mu \mathrm{M}:(A)$ rMRP1/2 proteins and (B) rKREPA4. The positions of free $\mathrm{gA6}[14]$ and protein-bound $\mathrm{gA6} 6$ [14] as resolved on the native TBE gels are indicated.

the inhibition. On the other hand, the interaction between KREPA4 and gA6[14] is effectively unperturbed by C35 (Fig. 2B). These data demonstrate that C35 directly binds to and inhibits the RNA binding activity of MRP1/2.

\section{Purified editosomes with lower MRP1/2 abundance exhibit increased susceptibility to C35 and MrB inhibition}

To assess the effect of MRP1/2 inhibition in the context of in vitro RNA editing activities, functional editosomes with differing abundances of MRP1/2 were prepared using tandem affinity purification (TAP) of tagged KREL1. The TAPtag fused to KREL1 contains two affinity tags, a protein A domain and a calmodulin-binding peptide, separated by a TEV protease cleavage site. This system allows for sequential purification of the tagged RECC through $\lg G$ agarose (TEV protease elution; "TEV eluate") and calmodulin affinity resins (EGTA elution; "Calmodulin eluate"). The resulting eluates were analyzed against the KREPA1, KREPA2, KREPA3, and KREL1 antibodies on a western blot, and eluate volumes corresponding to equal intensities were used in further experiments (data not shown). Equal band intensities on this western blot correlated to $90 \mathrm{ng} / \mu \mathrm{L}$ of total protein concentration in the TEV eluate versus $35 \mathrm{ng} / \mu \mathrm{L}$ of total protein concentration in the Calmodulin eluate, as estimated through Bradford quantification.

Ligase auto-adenylylation in the TEV eluate was only affected at a lower protein amount tested (90 ng) and enhanced at higher amounts (450 and $900 \mathrm{ng}$ ) (Fig. 3A), as observed previously (Moshiri et al. 2011). As this enhancement was earlier proposed to be a consequence of losing accessible ("ligatable") endogenous RNA, inhibition of MRP1/2 RNA interaction by the compounds indicates that these processes could be related. In other words, the compounds added at $10 \mu \mathrm{M}$ were sufficient for inhibiting the KRELs in $90 \mathrm{ng}$ of TEV eluate, but in larger quantities of TEV eluate, and therefore larger quantities of MRP1/2, the compounds were likely absorbed by MRP1/ 2 displacing the bound endogenous RNA off the MRP1/ 2 and RECC complexes and enhancing ligase auto-adenylylation. On the other hand, the compounds inhibit ligase auto-adenylylation in all quantities of the calmodulin eluate tested (Fig. 3A), as it contains approximately fivefold less MRP1/2 proteins than in the TEV eluate as estimated from band intensities on the western blot using ImageJ software (Fig. 3C). Consistently, the TEV eluate appeared more resistant to inhibition in the "precleaved" deletion assay, requiring $\mathrm{U}$-deletion and ligation activities (Fig. $3 B$ ). These data indicate that the MRP1/2 complex preferentially binds to the compounds, limiting inhibition of the ligase in the TEV eluate.

\section{C35 and MrB weaken the association between RECC and MRP1/2 and compromise in vitro editing}

To determine if inhibition of the MRP1/2 complex by the compounds displaces the heterotetramer off the RECC, KREL1 TEV eluate was bound to the Calmodulin Affinity resin in the presence of $\mathrm{C} 35, \mathrm{MrB}(20 \mu \mathrm{M}$ each), or RNase A $(0.1 \mathrm{mg} / \mathrm{mL})$ as a control. The EGTA elutions were performed after adequate washes to eliminate contaminating inhibitor or RNase A in the eluates. While western blots revealed a considerable loss in associated MRP2 in the eluates pretreated with the compounds and RNase A (Fig. 4A), these eluates also suffered from reduced in vitro editing activities in "full-round" and "precleaved" assays (Fig. 4B,C). This observation is concurrent with a previous study that shows suppression of in vitro editing 


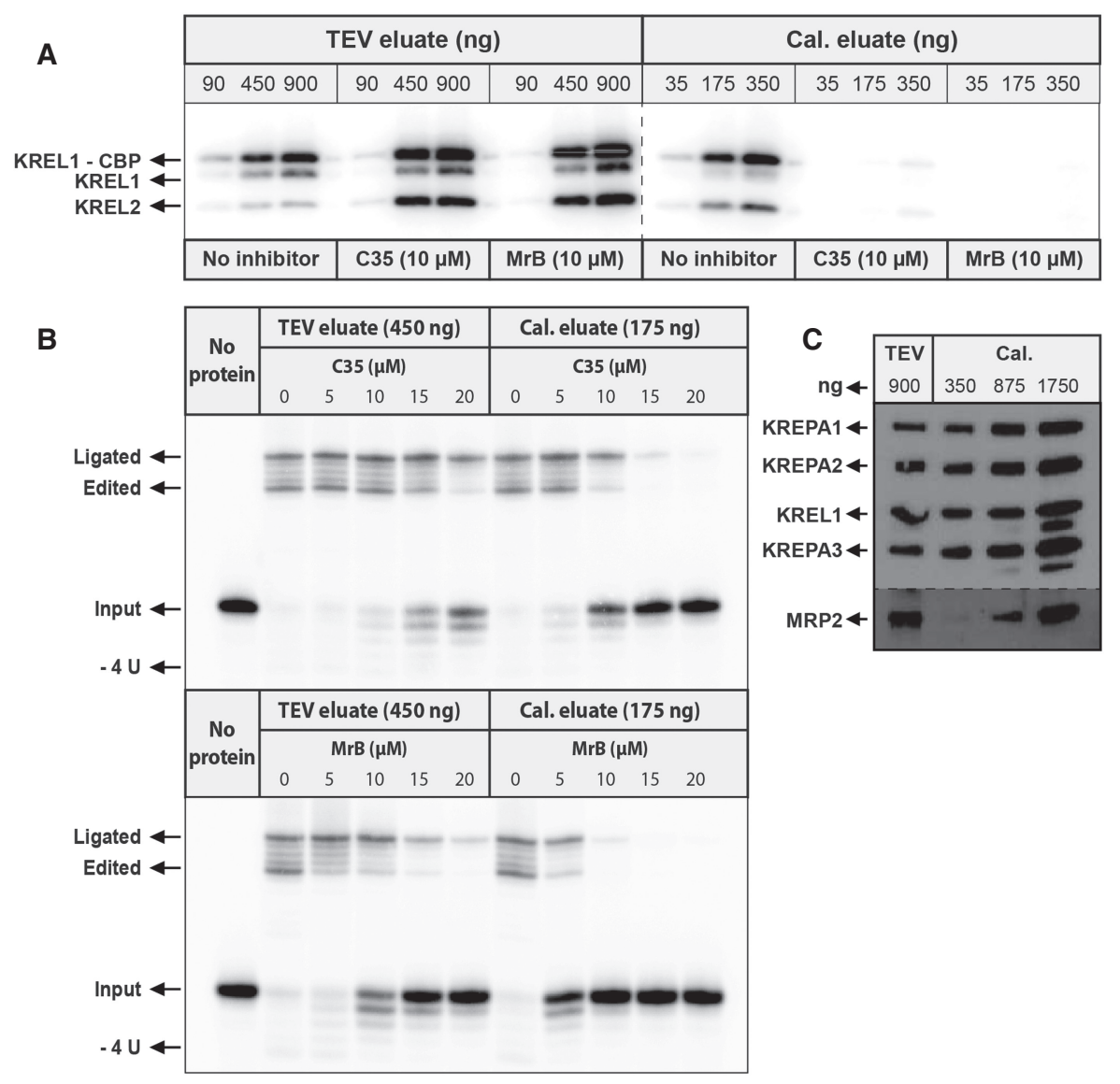

FIGURE 3. $\mathrm{C} 35$ and MrB inhibition of ligase auto-adenylylation and in vitro "precleaved" deletion in KREL1-TEV and Calmodulin eluates are correlated with MRP1/2 abundance. (A) KREL1 and KREL2 auto-adenylylation activities with various amounts of the KREL1-TEV and calmodulin eluates in the absence or presence of $\mathrm{C} 35$ and $\mathrm{MrB}$ (at $10 \mu \mathrm{M}$ ). Endogenous KREL1, KREL2, and KREL1-calmodulin fusion (KREL1-CBP) proteins are indicated. (B) In vitro "precleaved" deletion activities of both eluates in increasing amounts of C35 and MrB. (C) Western blot analysis showing the amount of MRP2 proteins in the two protein preparations. The eluates were precipitated with methanol for the purpose of concentrating them, prior to loading on the gel.

activity upon immunodepletion of MRP1 (Lambert et al. 1999). Remarkably, their activities are recovered upon the addition of the recombinant ( $r$ ) MRP1/2 proteins at $\sim 500 \mathrm{nM}$ (Fig. 4B,C). The required rMRP1/2 concentration was determined through 10-fold serial dilutions in the "full-round" FRET-based editing assay, tested with C35 and $\mathrm{MrB}$ pretreated calmodulin eluates (Supplemental Fig. S1 in Supplemental Information).

These data provide compelling experimental evidence that validates the presumed role of MRP1/2 heterotetramer in trypanosomatid RNA editing initiation. The MRP1/2 complex acts potentially through its gRNA/premRNA annealing activity to present the RNA duplex in a form that is accessible to the RECC, which can be inhibited by the sulfonated compounds $\mathrm{C} 35$ and $\mathrm{MrB}$, as modeled in Figure 5 (Muller et al. 2001; Muller and Goringer 2002; Aphasizhev et al. 2003; Schumacher et al. 2006; Ammerman et al. 2008; Zikova et al. 2008). This stimulatory effect of MRP1/2 on in vitro editing is concurrent with the effect of another RNA-binding protein with annealing ac- tivity, RBP16 (Miller et al. 2006), suggesting that the RECC requires accessory annealing factors for editing. While these observations are based on experiments conducted in vitro, these accessory factors may behave similarly in vivo and will require additional experiments to substantiate this conclusion. The other major finding of this study is the inhibition susceptibility of in vitro RNA editing by negatively charged compounds, as these compounds electrostatically compete away the RNA bound to the MRP1/2 proteins. We believe this mode of action extends to the RNA editing inhibitors previously found in the pilot scale screen conducted using the library of pharmacologically active compounds (LOPAC ${ }^{1280}$, Sigma), namely aurintricarboxylic acid (ATA), PPNDS and NF449, that not only affect RNA-protein interaction but also all catalytic activities required in editing in vitro (Moshiri et al. 2015). Preliminary analysis against suramin indicates a similar effect (data not shown), as it contains sulfonated naphthalene groups similar to C35 and MrB, and inhibits rKREL1 auto-adenylylation (Zimmermann et al. 2016). 
A

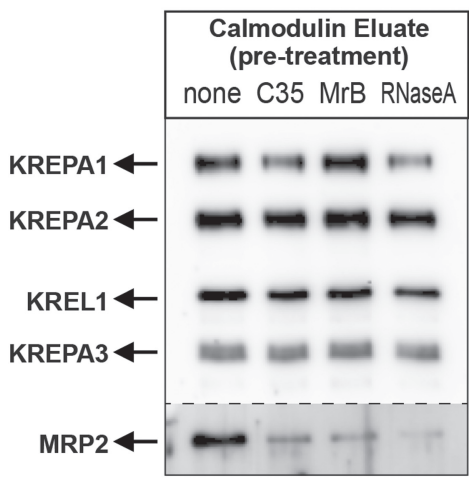

B
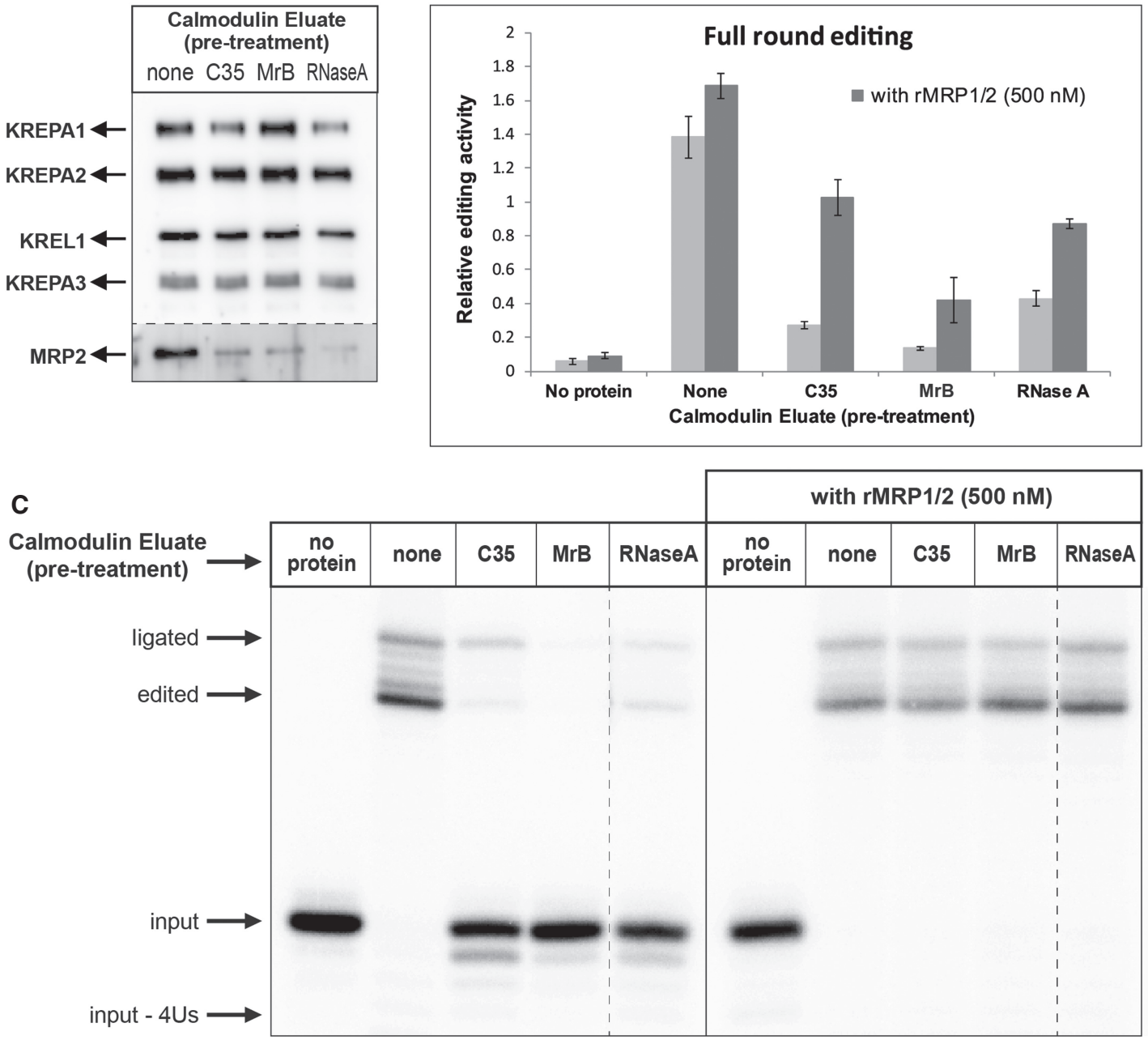

FIGURE 4. C35 and MrB disengage MRP1/2 association with RECC and suppress in vitro RNA editing activity. KREL1 Calmodulin eluates were prepared after treatment with $\mathrm{C} 35, \mathrm{MrB}$, and RNase A while binding to the Calmodulin affinity resin. (A) Western blot analysis against KREPA1, KREPA2, KREL1, and KREPA3 antibodies in the top panel and against MRP2 antibody in the bottom panel. Each lane contains 900 ng of the respective eluate. (B) "Full-round" and (C) "precleaved" RNA editing activities of these eluates in absence and presence of rMRP1/2 (500 nM).

\section{MATERIALS AND METHODS}

\section{Preparation of RNA and radiolabeling}

Electrophoretic mobility shift assays were performed with synthetic gA6[14] gRNA that specifies editing of the first editing site of the ATPase subunit 6 (A6) pre-mRNA. Preparation of gA6[14] gRNA was carried out via in vitro transcription of PCR amplified DNA template as described previously (Seiwert and Stuart 1994), and radiolabeled at the 3 '-terminus by incubating 50 pmol gA6[14] gRNA with $50 \mu \mathrm{Ci}$ of PcP [5'- $\left.{ }^{32} \mathrm{P}\right](3000 \mathrm{Ci} / \mathrm{mmol}$, $10 \mathrm{mCi} / \mathrm{mL}$ ) at $4^{\circ} \mathrm{C}$ overnight, in a total reaction volume of 20 $\mu \mathrm{L}$, containing $50 \mathrm{mM}$ Tris- $\mathrm{HCl}[\mathrm{pH} 7.5], 10 \mathrm{mM} \mathrm{MgCl}, 1 \mathrm{mM}$ ATP, $1 \mathrm{mM}$ DTT, $15 \%$ glycerol, 10\% DMSO, and 10 units of T4 RNA ligase 1 (New England Biolabs). RNA substrates required for the in vitro precleaved deletion editing assay (U5-5' CL, U5$3^{\prime} \mathrm{CLpp}$, and gA6[14]PC-del) were prepared as described previously (lgo et al. 2002). The $5^{\prime}$ fragment was radiolabeled at its $5^{\prime}$ terminus by incubating $50 \mathrm{pmol}$ of the RNA with $50 \mu \mathrm{Ci}$ of ATP $\left[\gamma_{-}{ }^{32} \mathrm{P}\right](3000 \mathrm{Ci} / \mathrm{mmol}, 10 \mathrm{mCi} / \mathrm{mL})$ at $37^{\circ} \mathrm{C}$ for $1 \mathrm{~h}$, in a 10 $\mu \mathrm{L}$ reaction, containing $70 \mathrm{mM}$ Tris- $\mathrm{HCl}[\mathrm{pH} 7.6], 10 \mathrm{mM} \mathrm{MgCl}$, $5 \mathrm{mM}$ DTT, and 10 units of T4 polynucleotide kinase (New England Biolabs). The radiolabeled RNA was PAGE-purified on a $9 \%(w / v) 7 M$ urea denaturing gel and quantified by scintillation counting. RNA substrates required in the in vitro FRET-based editing assay (pre-A6Rbz, gA6Rbz, gA6Rbz-comp, and FRET substrate) were prepared as described previously (Moshiri and Salavati 2010; Moshiri et al. 2014).

\section{Preparation of active proteins for functional studies}

The crude mitochondrial extract was prepared through hypotonic lysis of the procyclic stage $T$. brucei (strain IsTaR 1.7A) cells grown in SDM-79 media to late log phase $\left(\sim 2 \times 10^{7}\right.$ cells $\left./ \mathrm{mL}\right)$. Following glycerol gradient sedimentation $(10 \%-30 \%)$ of the crude 


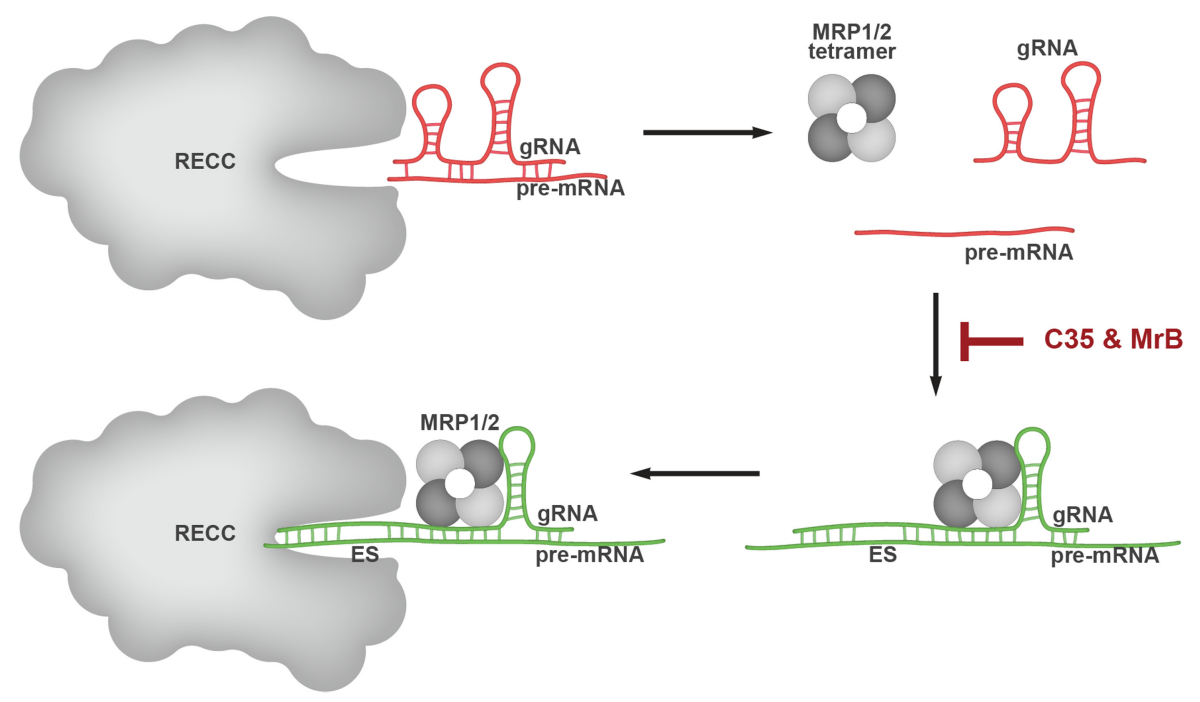

FIGURE 5. Model representing role of the MRP1/2 heterotetramer in RNA editing. The RECC or the editosome is incapable of initiating editing and requires the RNA annealing activity of the MRP1/2 heterotetramer for presenting the "editable" RNA duplex to the catalytic complex. C35 and $\mathrm{MrB}$ interfere with the RNA-binding capacity of MRP1/2, and therefore interfere with the RNA editing capacity of the core complex. ES indicates editing site.

mitochondrial lysate, $500 \mu \mathrm{L}$ fractions containing active in vitro RNA editing activity (F10-F12) were isolated (Panigrahi et al. 2003; Moshiri et al. 2014), pooled and concentrated to $50 \mu \mathrm{L}$ using Amicon Ultra $0.5 \mathrm{~mL}$ centrifugal filters. Immunoprecipitated editosomes were also prepared from KREL1-TAP 29.13 procyclic cells (Moshiri et al. 2011), wherein both IgG column (TEV protease release; named TEV eluate in this study) and calmodulin column preparations (EGTA release; named calmodulin eluate) were obtained and stored at $-80^{\circ} \mathrm{C}$. Recombinant ( $r$ ) MRP1/2 and KREPA4 proteins were purified as done previously (Zikova et al. 2008; Kala and Salavati 2010). To examine the presence of MRP1/2 in TEV and calmodulin eluates of KREL1-TAP, varying protein amounts from methanol precipitated eluates were analyzed by western blotting using the polyclonal antibody against MRP2, as described previously (Vondruskova et al. 2005).

\section{Electrophoretic mobility shift assays (EMSA)}

To identify the proteins affected by C35 treatment, editosomes partially purified by glycerol gradient sedimentation of the mitochondrial extract (concentrated fractions F10-F12) were used. An amount of $15 \mu \mathrm{L}$ of this preparation $(10 \mu \mathrm{g} / \mu \mathrm{L})$ was incubated with 5 pmol of unlabeled gA6[14] RNA and 0.5 pmol $\left(3 \times 10^{4}\right.$ CPM) of the $3^{\prime}$ end-labeled gA6 [14] RNA in a total $20 \mu \mathrm{L}$ of a mixture containing $20 \mathrm{mM}$ Tris- $\mathrm{HCl}[\mathrm{pH} 7.6], 150 \mathrm{mM} \mathrm{KCl}, 5 \mathrm{mM} \mathrm{MgCl}, 100$ $\mu \mathrm{g} / \mathrm{mL}$ BSA, $10 \%$ glycerol, $1 \mathrm{mM}$ DTT, and 20 units of RNasin ribonuclease inhibitor (Promega) for $30 \mathrm{~min}$ at room temperature. The RNA substrates were heated at $95^{\circ} \mathrm{C}$ for $5 \mathrm{~min}$ and cooled at room temperature prior to assembling the reactions. Samples were mixed with gel loading solution $(0.25 \%$ bromophenol blue, $0.25 \%$ xylene cyanol, and $30 \%$ glycerol) and run on $4 \%$ $(\mathrm{w} / \mathrm{v})$ native TBE gels as per the protocol (Kala and Salavati 2010). The gel run with unlabeled gA6[14] was stained using a colloidal Coomassie solution (BioRad), and the staining pattern was correlated with the RNA-protein complexes in the phosphor- image of the gel run with radiolabeled $\mathrm{gA6}$ [14]. The bands corresponding to the G1-G4 complex were excised from the gel run with unlabeled gA6[14] and analyzed by mass spectrometry.

To monitor the inhibitory effect of C35 on RNA binding proteins, increasing concentrations (0.1-1600 nM) of purified rMRP1/2 and rKREPA4 were first incubated in the presence and absence of $10 \mu \mathrm{M} \mathrm{C} 35$ on ice for $10 \mathrm{~min}$. These mixtures were then incubated with 0.5 pmol labeled gA6[14] for 30 min at room temperature as done above, run on $10 \%(\mathrm{w} / \mathrm{v})$ native TBE gels (BioRad) and visualized by phosphorimaging.

\section{Auto-adenylylation and in vitro RNA editing assays}

KREL1 auto-adenylylation assays were performed using various amounts of KREL1-TAP TEV and calmodulin eluates corresponding to $0.09,0.45$, and $0.9 \mu \mathrm{g}$ and $0.035,0.175$, and $0.35 \mu \mathrm{g}$ of total protein, respectively. The eluates were incubated in a $20 \mu \mathrm{L}$ reaction mixture containing $12.5 \mathrm{~mm} \operatorname{HEPES}(\mathrm{pH} 7.9), 25 \mathrm{mM} \mathrm{KCl}$, $5 \mathrm{mM}$ magnesium acetate, $0.25 \mathrm{mM}$ DTT, $40 \mathrm{nM}\left[\alpha_{-}{ }^{32} \mathrm{P}\right]$ ATP $(3000 \mathrm{Ci} / \mathrm{mmol}, 10 \mathrm{mCi} / \mathrm{mL}), 0.1 \%(\mathrm{w} / \mathrm{v})$ Triton $\mathrm{X}-100$, and $5 \%$ (v/v) of DMSO (control) or $1 \mu \mathrm{L}$ of $200 \mu \mathrm{M} \mathrm{C} 35$ or MrB (dissolved in DMSO; corresponding to $10 \mu \mathrm{M}$ in a $20 \mu \mathrm{L}$ reaction), as described elsewhere (Moshiri et al. 2011). The proteins were preincubated with the respective compounds on ice for 5 min prior to reaction assembly. The adenylylation reactions were allowed to run at $28^{\circ} \mathrm{C}$ for $10 \mathrm{~min}$, stopped by the addition of SDS loading buffer and resolved on 10\% SDS-PAGE gel. Radiolabeled proteins were detected by phosphorimaging.

In vitro precleaved RNA editing assays were performed following procedures from literature (lgo et al. 2002). RNA substrates required for the precleaved deletion assay, $\left[\gamma^{32} \mathrm{P}\right] \mathrm{U} 5-5^{\prime} \mathrm{CL}$, U5-3'CLpp, and gA6[14]PC-del were mixed in a ratio of 0.25:1:0.5 pmol, heated at $65^{\circ} \mathrm{C}$ for $2 \mathrm{~min}$ and cooled down to room temperature. Editing reactions were prepared by assembling $5 \mu \mathrm{L}$ of TEV eluate $(0.45 \mu \mathrm{g}$ of total protein) or $5 \mu \mathrm{L}$ of calmodulin eluate 
$(0.175 \mu \mathrm{g}$ of total protein) with the RNA mixture, in a $20 \mu \mathrm{L}$ solu-

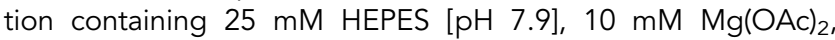
$1 \mathrm{mM}$ EDTA, $5 \mathrm{mM} \mathrm{CaCl}$, $10 \mu \mathrm{M}$ ATP, 0.1\% Triton X-100 (w/v), $16.7 \mathrm{ng} / \mu \mathrm{L}$ Torula yeast RNA, 15 units of RNasin plus ribonuclease inhibitor, and $0.5 \mathrm{mM}$ DTT. rMRP1/2 was added in the reactions as indicated. The editing reactions were allowed to proceed for $3 \mathrm{~h}$ at $28^{\circ} \mathrm{C}$ and stopped by the addition of $2 \mu \mathrm{l}$ of $260 \mathrm{mM}$ EDTA-2.5\% sodium dodecyl sulfate mixture. RNA was then extracted using phenol:chloroform:isoamyl alcohol (25:24:1), precipitated and resuspended in $10 \mathrm{M}$ urea dye before running onto $15 \%(w / v) 7 \mathrm{M}$ urea denaturing polyacrylamide gel and visualized by phosphorimaging. Full-round FRET-based RNA editing assay was performed identically as described previously (Moshiri and Salavati 2010; Moshiri et al. 2014). rMRP1/2 was added in the reactions as indicated.

\section{SUPPLEMENTAL MATERIAL}

Supplemental material is available for this article.

\section{ACKNOWLEDGMENTS}

We thank Eva Černotíková-Stříbrná for the purification of recombinant MRP1/2. This work was supported by the Canadian Institutes of Health Research (grant number: 119464) to R.S., the Training Initiative in Chemical Biology to V.M., and the Grant Agency of the Czech Republic (fund number: 204/09/ 1667) and the Praemium Academiae award to J.L.

Received March 29, 2020; accepted April 6, 2020.

\section{REFERENCES}

Allen TE, Heidmann S, Reed R, Myler PJ, Goringer HU, Stuart KD. 1998. Association of guide RNA binding protein gBP21 with active RNA editing complexes in Trypanosoma brucei. Mol Cell Biol 18: 6014-6022. doi:10.1128/MCB.18.10.6014

Amaro RE, Schnaufer A, Interthal H, Hol W, Stuart KD, McCammon JA. 2008. Discovery of drug-like inhibitors of an essential RNA-editing ligase in Trypanosoma brucei. Proc Natl Acad Sci 105: 1727817283. doi:10.1073/pnas.0805820105

Ammerman ML, Fisk JC, Read LK. 2008. gRNA/pre-mRNA annealing and RNA chaperone activities of RBP16. RNA 14: 1069-1080. doi:10.1261/rna.982908

Ammerman ML, Presnyak V, Fisk JC, Foda BM, Read LK. 2010. TbRGG2 facilitates kinetoplastid RNA editing initiation and progression past intrinsic pause sites. RNA 16: 2239-2251. doi:10 $.1261 /$ rna.2285510

Ammerman ML, Hashimi H, Novotna L, Cicova Z, McEvoy SM, Lukes J, Read LK. 2011. MRB3010 is a core component of the MRB1 complex that facilitates an early step of the kinetoplastid RNA editing process. RNA 17: 865-877. doi:10.1261/rna.2446311

Ammerman ML, Tomasello DL, Faktorova D, Kafkova L, Hashimi H, Lukes J, Read LK. 2013. A core MRB1 complex component is indispensable for RNA editing in insect and human infective stages of Trypanosoma brucei. PLoS ONE 8: e78015. doi:10.1371/journal pone.0078015

Aphasizhev R, Aphasizheva I. 2011. Uridine insertion/deletion editing in trypanosomes: a playground for RNA-guided information transfer. Wiley Interdiscip Rev RNA 2: 669-685. doi:10.1002/wrna.82
Aphasizhev R, Aphasizheva I, Nelson RE, Simpson L. 2003. A 100-kD complex of two RNA-binding proteins from mitochondria of Leishmania tarentolae catalyzes RNA annealing and interacts with several RNA editing components. RNA 9: 62-76. doi:10 $.1261 /$ rna.2134303

Aphasizheva I, Zhang L, Wang X, Kaake RM, Huang L, Monti S, Aphasizhev R. 2014. RNA binding and core complexes constitute the U-insertion/deletion editosome. Mol Cell Biol 34: 4329-4342. doi:10.1128/MCB.01075-14

Blom D, Burg J, Breek CK, Speijer D, Muijsers AO, Benne R. 2001. Cloning and characterization of two guide RNA-binding proteins from mitochondria of Crithidia fasciculata: gBP27, a novel protein, and gBP29, the orthologue of Trypanosoma brucei gBP21. Nucleic Acids Res 29: 2950-2962. doi:10.1093/nar/29.14.2950

Blum B, Bakalara N, Simpson L. 1990. A model for RNA editing in kinetoplastid mitochondria: "guide" RNA molecules transcribed from maxicircle DNA provide the edited information. Cell 60: 189-198. doi:10.1016/0092-8674(90)90735-W

Dixit S, Lukeš J. 2018. Combinatorial interplay of RNA-binding proteins tunes levels of mitochondrial mRNA in trypanosomes. RNA 24: 1594-1606. doi:10.1261/rna.066233.118

Doherty AJ, Suh SW. 2000. Structural and mechanistic conservation in DNA ligases. Nucleic Acids Res 28: 4051-4058. doi:10.1093/nar/ 28.21.4051

Drozdz M, Palazzo SS, Salavati R, O’Rear J, Clayton C, Stuart K. 2002. TbMP81 is required for RNA editing in Trypanosoma brucei. EMBO J 21: 1791-1799. doi:10.1093/emboj/21.7.1791

Durrant JD, Hall L, Swift RV, Landon M, Schnaufer A, Amaro RE. 2010. Novel naphthalene-based inhibitors of Trypanosoma brucei RNA editing ligase 1. PLoS Negl Trop Dis 4: e803. doi:10.1371/jour nal.pntd.0000803

Fisk JC, Ammerman ML, Presnyak V, Read LK. 2008. TbRGG2, an essential RNA editing accessory factor in two Trypanosoma brucei life cycle stages. J Biol Chem 283: 23016-23025. doi:10.1074/ jbc.M801021200

Fisk JC, Presnyak V, Ammerman ML, Read LK. 2009. Distinct and overlapping functions of MRP1/2 and RBP16 in mitochondrial RNA metabolism. Mol Cell Biol 29: 5214-5225. doi:10.1128/MCB.0052009

Gao G, Simpson L. 2003. Is the Trypanosoma brucei REL1 RNA ligase specific for U-deletion RNA editing, and is the REL2 RNA ligase specific for U-insertion editing? J Biol Chem 278: 27570-27574. doi:10.1074/jbc.M303317200

Hashimi H, Cicova Z, Novotna L, Wen YZ, Lukes J. 2009. Kinetoplastid guide RNA biogenesis is dependent on subunits of the mitochondrial RNA binding complex 1 and mitochondrial RNA polymerase. RNA 15: 588-599. doi:10.1261/rna.1411809

Huang CE, Cruz-Reyes J, Zhelonkina AG, O'Hearn S, Wirtz E, SollnerWebb B. 2001. Roles for ligases in the RNA editing complex of Trypanosoma brucei: band IV is needed for U-deletion and RNA repair. EMBO J 20: 4694-4703. doi:10.1093/emboj/20.17.4694

Igo RP Jr, Weston DS, Ernst NL, Panigrahi AK, Salavati R, Stuart K. 2002. Role of uridylate-specific exoribonuclease activity in Trypanosoma brucei RNA editing. Eukaryot Cell 1: 112-118. doi:10.1128/EC.1.1.112-118.2002

Kala S, Salavati R. 2010. OB-fold domain of KREPA4 mediates high-affinity interaction with guide RNA and possesses annealing activity. RNA 16: 1951-1967. doi:10.1261/rna.2124610

Koller J, Muller UF, Schmid B, Missel A, Kruft V, Stuart K, Goringer HU. 1997. Trypanosoma brucei gBP21. An arginine-rich mitochondrial protein that binds to guide RNA with high affinity. $\mathrm{J} \mathrm{Biol} \mathrm{Chem}$ 272: 3749-3757. doi:10.1074/jbc.272.6.3749

Lambert L, Muller UF, Souza AE, Goringer HU. 1999. The involvement of gRNA-binding protein gBP21 in RNA editing-an in vitro and in 
vivo analysis. Nucleic Acids Res 27: 1429-1436. doi:10.1093/nar/ 27.6.1429

Miller MM, Halbig K, Cruz-Reyes J, Read LK. 2006. RBP16 stimulates trypanosome RNA editing in vitro at an early step in the editing reaction. RNA 12: 1292-1303. doi:10.1261/rna.2331506

Moshiri H, Salavati R. 2010. A fluorescence-based reporter substrate for monitoring RNA editing in trypanosomatid pathogens. Nucleic Acids Res 38: e138. doi:10.1093/nar/gkq333

Moshiri H, Acoca S, Kala S, Najafabadi HS, Hogues H, Purisima E, Salavati R. 2011. Naphthalene-based RNA editing inhibitor blocks RNA editing activities and editosome assembly in Trypanosoma brucei. J Biol Chem 286: 14178-14189. doi:10.1074/jbc.M110 .199646

Moshiri H, Mehta V, Salavati R. 2014. RNA catalyst as a reporter for screening drugs against RNA editing in trypanosomes. J Vis Exp 2014: 51712. doi:10.3791/51712

Moshiri H, Mehta V, Yip CW, Salavati R. 2015. Pilot-scale compound screening against RNA editing identifies trypanocidal agents. J Biomol Screen 20: 92-100. doi:10.1177/1087057114548833

Muller UF, Goringer HU. 2002. Mechanism of the gBP21-mediated RNA/RNA annealing reaction: matchmaking and charge reduction. Nucleic Acids Res 30: 447-455. doi:10.1093/nar/30.2.447

Muller UF, Lambert L, Goringer HU. 2001. Annealing of RNA editing substrates facilitated by guide RNA-binding protein gBP21. EMBO J 20: 1394-1404. doi:10.1093/emboj/20.6.1394

Osato D, Rogers K, Guo Q, Li F, Richmond G, Klug F, Simpson L. 2009. Uridine insertion/deletion RNA editing in trypanosomatid mitochondria: in search of the editosome. RNA 15: 1338-1344. doi:10.1261/rna.1642809

Panigrahi AK, Schnaufer A, Ernst NL, Wang B, Carmean N, Salavati R, Stuart K. 2003. Identification of novel components of Trypanosoma brucei editosomes. RNA 9: 484-492. doi:10.1261/ rna.2194603

Read LK, Lukeš J, Hashimi H. 2016. Trypanosome RNA editing: the complexity of getting $U$ in and taking $U$ out. Wiley Interdiscip Rev RNA 7: 33-51. doi:10.1002/wrna.1313

Salavati R, Ernst NL, O'Rear J, Gilliam T, Tarun S Jr, Stuart K. 2006. KREPA4, an RNA binding protein essential for editosome integrity and survival of Trypanosoma brucei. RNA 12: 819-831. doi:10 $.1261 /$ rna. 2244106

Salavati R, Moshiri H, Kala S, Najafabadi HS. 2012. Inhibitors of RNA editing as potential chemotherapeutics against trypanosomatid pathogens. Int J Parasitol 2: 36-46. doi:10.1016/j.ijpddr.2011.10.003

Schnaufer A, Panigrahi AK, Panicucci B, Igo RP Jr, Wirtz E, Salavati R, Stuart K. 2001. An RNA ligase essential for RNA editing and survival of the bloodstream form of Trypanosoma brucei. Science 291: 2159-2162. doi:10.1126/science. 1058655
Schnaufer A, Ernst NL, Palazzo SS, O'Rear J, Salavati R, Stuart K. 2003. Separate insertion and deletion subcomplexes of the Trypanosoma brucei RNA editing complex. Mol Cell 12: 307319. doi:10.1016/S1097-2765(03)00286-7

Schumacher MA, Karamooz E, Zikova A, Trantirek L, Lukes J. 2006. Crystal structures of $T$. brucei MRP1/MRP2 guide-RNA binding complex reveal RNA matchmaking mechanism. Cell 126: 701711. doi:10.1016/j.cell.2006.06.047

Seiwert SD, Stuart K. 1994. RNA editing: transfer of genetic information from gRNA to precursor mRNA in vitro. Science 266: 114117. doi:10.1126/science.7524149

Simpson L, Thiemann OH, Savill NJ, Alfonzo JD, Maslov DA. 2000. Evolution of RNA editing in trypanosome mitochondria. Proc Natl Acad Sci 97: 6986-6993. doi:10.1073/pnas.97.13.6986

Simpson L, Sbicego S, Aphasizhev R. 2003. Uridine insertion/deletion RNA editing in trypanosome mitochondria: a complex business. RNA 9: 265-276. doi:10.1261/rna.2178403

Sturm NR, Simpson L. 1990. Kinetoplast DNA minicircles encode guide RNAs for editing of cytochrome oxidase subunit III mRNA. Cell 61: 879-884. doi:10.1016/0092-8674(90)90198-N

Vondruskova E, van den Burg J, Zikova A, Ernst NL, Stuart K, Benne R, Lukes J. 2005. RNA interference analyses suggest a transcript-specific regulatory role for mitochondrial RNA-binding proteins MRP1 and MRP2 in RNA editing and other RNA processing in Trypanosoma brucei. J Biol Chem 280: 2429-2438. doi:10 .1074/jbc.M405933200

Weng J, Aphasizheva I, Etheridge RD, Huang L, Wang X, Falick AM, Aphasizhev R. 2008. Guide RNA-binding complex from mitochondria of trypanosomatids. Mol Cell 32: 198-209. doi:10.1016/j .molcel.2008.08.023

Worthey EA, Schnaufer A, Mian IS, Stuart K, Salavati R. 2003. Comparative analysis of editosome proteins in trypanosomatids. Nucleic Acids Res 31: 6392-6408. doi:10.1093/nar/gkg870

Zikova A, Horakova E, Jirku M, Dunajcikova P, Lukes J. 2006. The effect of down-regulation of mitochondrial RNA-binding proteins MRP1 and MRP2 on respiratory complexes in procyclic Trypanosoma brucei. Mol Biochem Parasitol 149: 65-73. doi:10 .1016/j.molbiopara.2006.04.007

Zikova A, Kopecna J, Schumacher MA, Stuart K, Trantirek L, Lukes J. 2008. Structure and function of the native and recombinant mitochondrial MRP1/MRP2 complex from Trypanosoma brucei. Int J Parasitol 38: 901-912. doi:10.1016/j.ijpara.2007.12.009

Zimmermann S, Hall L, Riley S, Sorensen J, Amaro RE, Schnaufer A. 2016. A novel high-throughput activity assay for the Trypanosoma brucei editosome enzyme REL1 and other RNA ligases. Nucleic Acids Res 44: e24. doi:10.1093/nar/gkv938 

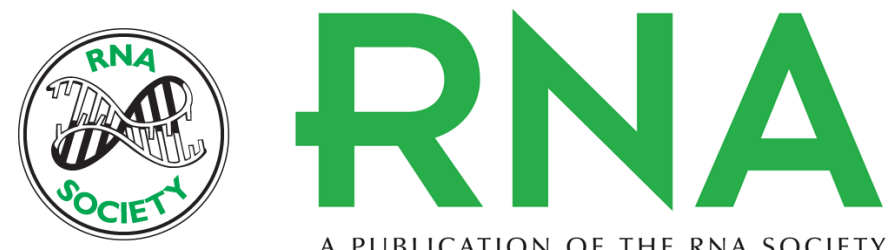

A PUBLICATION OF THE RNA SOCIETY

\section{Sulfonated inhibitors of the RNA editing ligases validate the essential role of the MRP1/2 proteins in kinetoplastid RNA editing}

Vaibhav Mehta, Houtan Moshiri, Akshaya Srikanth, et al.

RNA 2020 26: 827-835 originally published online April 10, 2020

Access the most recent version at doi:10.1261/rna.075598.120

\section{Supplemental http://rnajournal.cshlp.org/content/suppl/2020/04/10/rna.075598.120.DC1 \\ Material}

References This article cites 49 articles, 28 of which can be accessed free at: http://rnajournal.cshlp.org/content/26/7/827.full.html\#ref-list-1

Open Access Freely available online through the RNA Open Access option.

Creative This article, published in $R N A$, is available under a Creative Commons License Commons (Attribution 4.0 International), as described at

License http://creativecommons.org/licenses/by/4.0/.

Email Alerting Receive free email alerts when new articles cite this article - sign up in the box at the Service top right corner of the article or click here.

To subscribe to $R N A$ go to:

http://rnajournal.cshlp.org/subscriptions 